\title{
Farming and land use changes in Cerrado biome: the case of East Maranhão - Brazil (1985/2018)
}

\author{
Thiago José Arruda de Oliveira² \\ Stefan Hubertus Dorner ${ }^{3}$ \\ Waldecy Rodrigues ${ }^{4}$
}

\begin{abstract}
This paper analyzed the reasons for land use changes in Caxias, East Maranhão, in the Northeast region of Brazil, between 1985 and 2018. The analyzed region is located in MATOPIBA, which includes the states of Maranhão, Tocantins, Piauí and Bahia, part of the Cerrado and also known as the last agricultural frontier. Remote sensing using MapBioma to detect the location of forest lands and farming fields was applied combined with IBGE database about the agricultural production. Additionally, the application of questionnaires and interviews with regional soybean farmers and stakeholders was used to obtain additional empirical information. The following four categories probably responsible for those land use changes were analyzed: (1) infrastructure/investments in facilities, (2) environment/availability of natural cover for agriculture, (3) economy/entrance of global agribusiness companies; and (4) demography/number of smallholder's properties. Even though soy production has increased significantly in Maranhão, due to large investments in infrastructure and IT, the main responsible for deforestation and changes in land cover in the Caxias region has been pasture and cattle breeding. Tight environmental procedures and strong difficulties to acquire large areas of suitable land for high-tech commodity production have been the main obstacles for more significant advances of soybean production in Caxias. Thus, protection of forests, multitask agricultural activities, sustainable cattle breeding and soy production as part of a global supply chain should be harmonized in order to guarantee well-balanced co-existing and development.
\end{abstract}

Keywords: Remote sensing. Land use. Farming production. Maranhão.

\footnotetext{
${ }^{1}$ We would like to acknowledge the financial support given by the Coordination for the Improvement of Higher Education Personnel (Coordenação de Aperfeiçoamento de Pessoal de Nível Superior - CAPES), the administrative support granted by the Postgraduate Program of Regional Development of the Federal University of Tocantins (Programa de Pós-Graduação em Desenvolvimento Regional da Universidade Federal do Tocantins -PGDR/UFT), the Federal Institute of Maranhão. Campus São Luís - Maracanã (IFMA) and the technical advice by Dr. Rodolfo Alves da Luz (UFT/Porto Nacional).

2 PhD. Regional Development and Agribusiness (UNIOESTE). Pos-doc fellowship at Pos Graduation Program of Regional Development, Federal University of Tocantins, Brazil (UFT). https://orcid.org/0000-0002-7090-0202. thiago.arruda85@gmail.com

${ }^{3}$ PhD. Regional Development and Agribusiness (UNIOESTE). Professor in Federal Institute of Maranhão, Brazil (IFMA). https://orcid.org/0000-0002-2665-8615.stefan.doerner@ifma.edu.br

${ }^{4}$ PhD. Social Sciences (UnB). Professor in B.A. Economic Sciences/Pos-Graduation Program of Regional Development, Federal University of Tocantins, Brazil (UFT). https://orcid.org/0000-0002-5584-6586. waldecy@terra.com.br.
} 


\section{Agropecuária e mudanças no uso do solo no Cerrado: o caso do leste do Maranhão-Brasil (1985-2018)}

\section{Resumo.}

O artigo analisou as mudanças no uso do solo na Região de Caxias, Leste do Maranhão, Nordeste do Brasil, entre os anos de 1985 e 2018. Essa delimitação encontra-se no MATOPIBA (Maranhão, Tocantins, Piauí e Bahia), parte do Cerrado. Para tanto, utilizou o mosaico de imagens do Mapbioma para detectar a localização das florestas e campos agrícolas e dos dados agropecuários fornecidos pelo IBGE. Além disso, empregou-se as informações obtidas por meio de entrevistas e questionários aplicados aos produtores de soja da região e stakeholders dessa cadeia como forma de obter informações empíricas adicionais. Enumerou-se as seguintes categorias para analisar as motivações que acarretaram as mudanças do uso do solo na região: (1) melhorias na infraestrutura, (2) disponibilidade de solos para a agricultura, (3) entrada de companhias globais do agronegócio no Brasil, e (4) quantidade significativa de pequenos produtores rurais. Apesar do aumento da sojicultura no Leste do Maranhão, impulsionada pelos investimentos em infraestrutura e $\mathrm{Tl}$, a pastagem, usado para a alimentação do gado, foi o principal responsável pelas mudanças no uso do solo na região. Dentre as principais dificuldade enfrentadas pelos sojicultores, a demora em obter licenças ambientais e a de adquirir tecnologia para a produção agrícola em larga escala são os principais obstáculos. Dessa forma, o grande desafio do Leste do Maranhão é garantir a proteção dos seus recursos naturais sem comprometer a agricultura familiar, a pecuária bovina e a produção de soja.

Palavras-chaves: Sensoriamento remoto. Uso do solo. Produção agropecuária. Maranhão

\section{Introduction}

Farming is the main cause of land use and changes in tropical countries (KONG et al., 2018)). In Brazil, the replacement of natural cover into agricultural fields is linked to the soybean complex advance, the most noteworthy national rural production (BRASIL, 2019b; ARAÚJO et al., 2019).

The rise of soybean production began when a couple of Dutch immigrants and the Brazilian Agricultural Research Corporation (EMBRAPA) developed cultivates specially adapted to Cerrado biome during the 1970s (DUTRA; AREND, 2015). Agricultural aptitude, innovation, and growing global demand in the following decades boosted Brazilian farming earnings in the following decades (ELIAS, 2015; OLIVEIRA; RODRIGUES, 2019). As a consequence, grain fields expanded widely in Brazil, mainly in large flat areas between the North and Northeast regions known as MATOPIBA, which includes the states of Maranhão (MA), Tocantins (TO), Piauí (PI) and Bahia (BA) (ELIAS, 2015; BECKMANN; SANTANA, 2019; SANO et al, 2019). 
In the MATOPIBA region, agricultural sprawl led to a robustly rural-urban association based on agricultural industry and new trade partners (ELIAS, 2017; 2018). This development is notably as its context differs from the evolution of some European countries such as Portugal and Sweden, where most of the rural properties were sold for real estate development or abandoned by their owners, resulting in degeneration of those areas (ABRAMSON; HAGBERG, 2018; GOMES et al., 2018).

In Maranhão, a state in the Brazilian Northeast, grain, specially soybeans, expanded in the southern zone (DORNER et al., 2019). Previously, particularly between the 18th and 20th century, the farmlands were concentrated in the central and eastern zones, dedicated to the cultivation of cotton (Figure 1). Nevertheless, insufficient credits and lack of investments in infrastructure and technology weakened the activity. This scenario differs from the current situation of soybean production, strongly supported by national and multinational companies and marked by significant investments in innovation and technology (ALMEIDA; MATTOS JÚNIOR, 2016; PERPETUA et al, 2019).

Figure 1. Infrastructure and localization of cotton (1775-1970) and soybean (1980-2017) production in the state of Maranhão, Brazil.

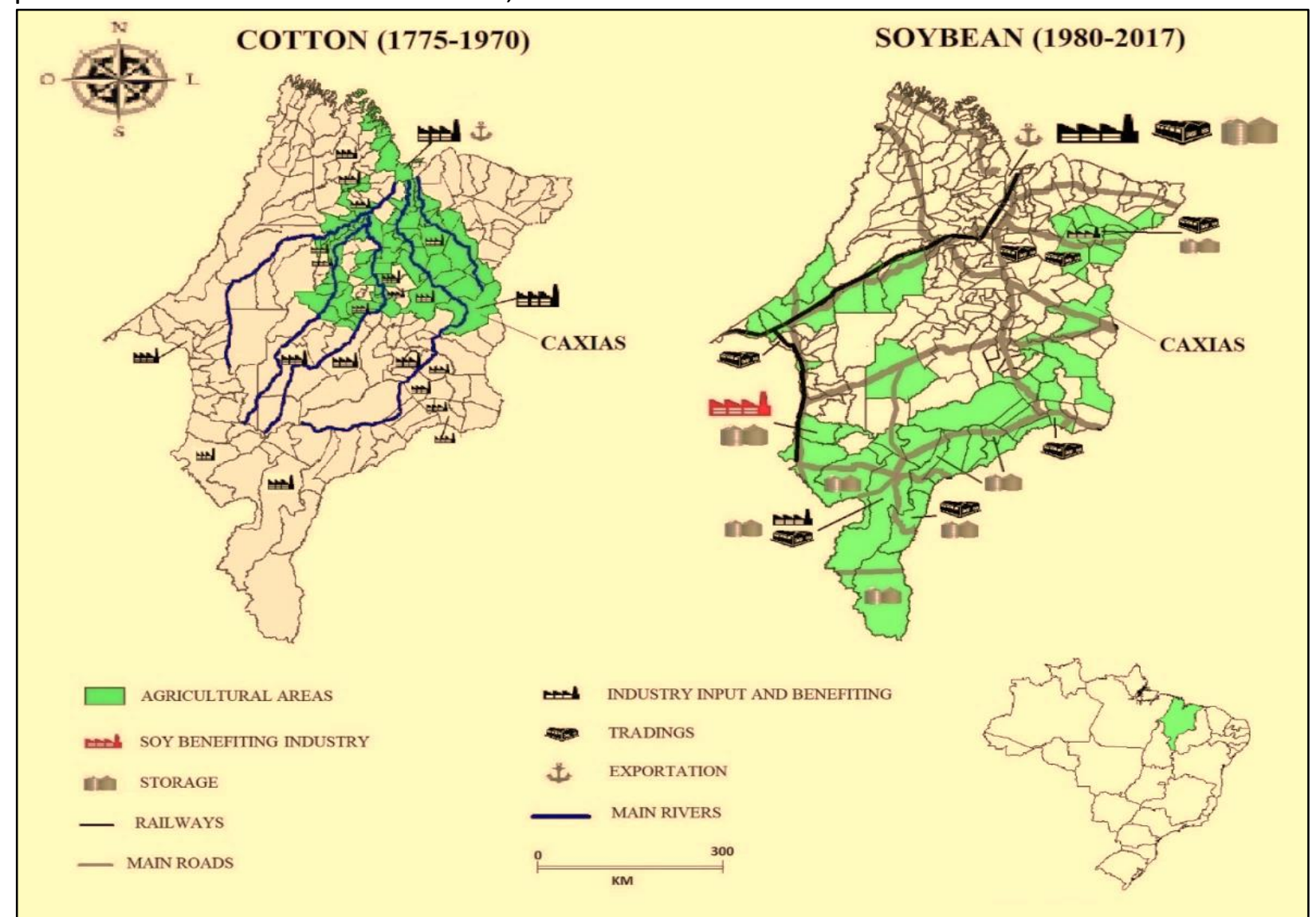

Adapted from: Dorner et al. (2019). 
Recently, soybean fields have advanced into previously cotton areas, mainly in the municipality of Caxias (Figure 1), earlier an important center of production and commercialization of this culture and located near to two subregions ${ }^{5}$ with significant soybean production: Chapadinha, in the northeast, and Colinas, in the southeast. In this area, soybean yields increased by 31\% between 2010 and 2017 (BRASIL, 2019a). As there is spare empiric evidence about the reasons for changes in land use and agricultural production in the East Maranhão, we decided to undertake further investigation and respond if soybean has become the leading agricultural activity in this area, previously dominated by cotton.

\section{Material and methods}

\subsection{Research area and proceedings}

The Region of Caxias, which includes three subregions, Codó, Caxias and Timon (Figure 2) is located in the Eastern part of Maranhão, borders the state of Piauí and covers $27,873 \mathrm{~km}^{2}$ with a total population of 775,925 in 2018 (BRASIL, 2019c). It experienced well population growth of 0.8\% between 2008 and 2018, during the expansion of soybean production (BRASIL, 2019c). Most people of this region reside in the towns of Timon $(167,973$ inhabitants), Caxias $(164,334$ inhabitants) and Codó (122,597 inhabitants), nevertheless, a large part of its population still lives outside the urban centers.

\footnotetext{
${ }^{5}$ The regions and subregions used in this work are official references prepared by the Brazilian Institute of Geography and Statistics (IBGE).
} 
Figure 2. Localization of study area

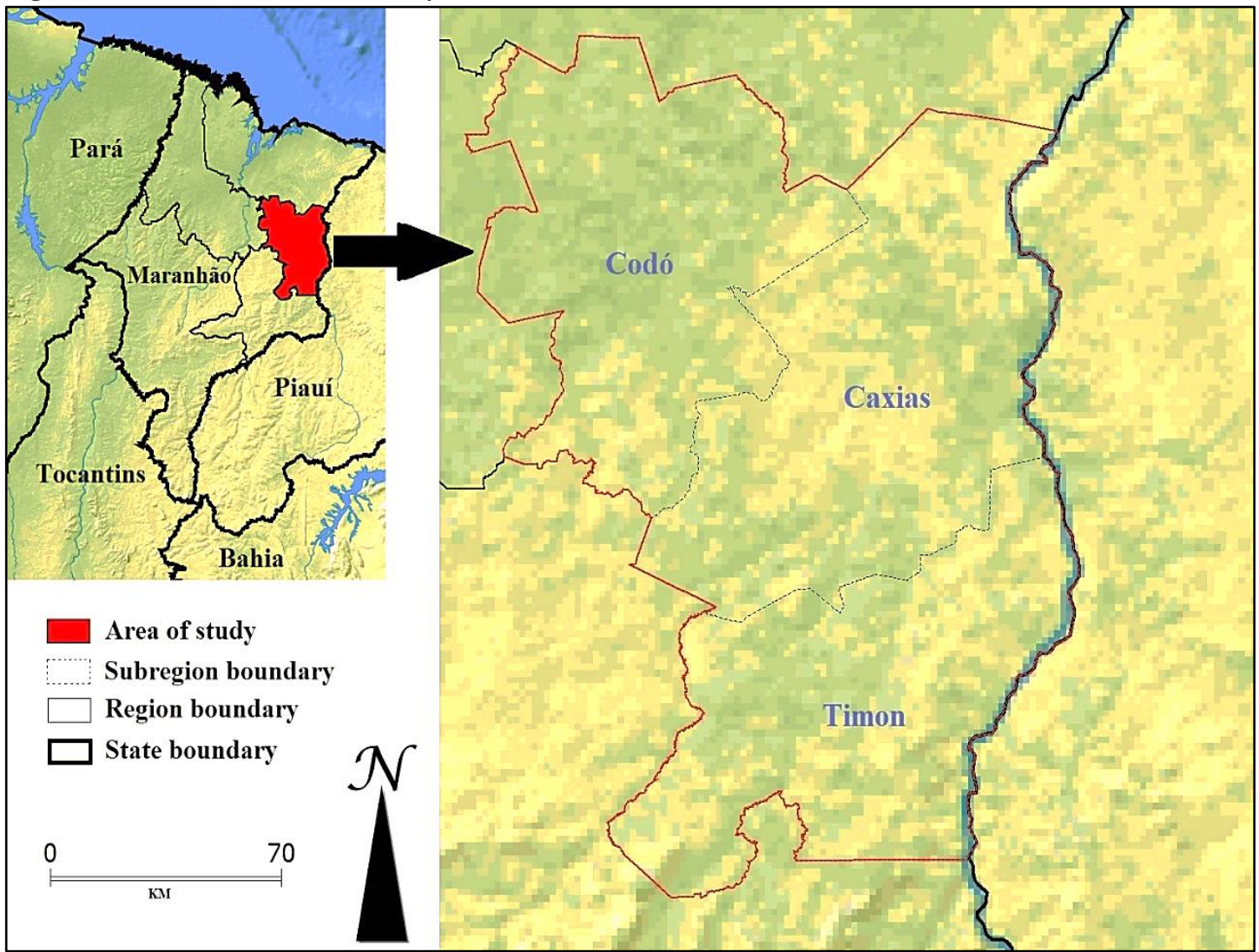

Elaborated by authors.

The following methods have been applied to investigate possible changes in land use and agricultural production in Eastern Maranhão between 1985 and 2018, a period in which most of the regional agrarian production transformations took place: (1) remote sensing available from MapBioma to detect the location of forest lands and farming fields; (2) Agricultural production framework and (3) field research through the perceptions of regional soybean farmers and other stakeholders, to identify probable causes that may explain the results obtained in the first two topics.

\subsection{Land use classification and data collection}

MapBioma is part of the Climate Observatory, which purposes constant mapping of Brazil's land use and detects any land cover changes through Landsat multispectral scanner (MAPBIOMA, 2019). The images were acquired from the Google Earth Engine site for six single years: $1985,1995,2005,2010,2015$, and 2018, including three crucial periods: the development of soybeans adapted to Cerrado (1985/1995), the increase in national agribusiness (2005/2010), 
and the consolidation of agriculture commodities (2015/2018). All obtained images were preprocessed and classified according to the Brazilian Institute of Geography and Statistics (IBGE), the Food and Agricultural Organization (FAO) and the Intergovernmental Panel Climate Changes (IPCC) patterns.

In order to facilitate visual interpretation, six classes were distinguished: forest formation (dark green), savanna formation (light green), pasture (yellow), agriculture (magenta), urban infrastructure (red), and other formations (light yellow). The photo-images were compared with the Google Earth database to assure reliability and graphic illustration and to summarize information about the variations in land use changes during the analyzed period.

However, as MapBioma does not offer information about existing agriculture crops in the region, we used data of agricultural production and Farming Census for each municipality provided by IBGE. The IBGE data base contains statistical information on planted area, quantity and dimension of rural properties, always classified by each agricultural product and per year.

Among possible causes to explain farming advance and consequently land use changes in East Maranhão, four categories and their respective primary factors were built through preclassification scheme developed and successfully applied by Kong et al. (2018) in a study about land use and land cover changes in the Northwestern Cambodian uplands: (1) infrastructure/investments in facilities, (2) environment/availability of natural cover for agriculture, (3) economy/entrance of global agribusiness companies; and (4) demography/number of smallholder's properties. Afterwards, those categories were crosschecked and validated through triangulation with information obtained by interviews with 88 operating agents of the agri-industrial soybean system (45 farmers, 19 suppliers, six traders and 18 supporting participants) during 2015/2016 crop (DORNER, 2017). Full access to questionnaires and transcriptions was granted, names preserved, and only information of respondents involved in activities related to the region of Caxias employed (table 1).

Table 1. Categories and primary factors responsible for farming advance

\begin{tabular}{llc}
\hline Category & Primary factor & Period \\
\hline Infrastructure & Investments in facilities & $2010 / 2018$ \\
Environment & Availability of natural cover for agriculture & $1985 / 2018$ \\
Economy & Entry of global agribusiness companies & $1995 / 2018$ \\
Demography & Number of smallholder's properties & $1985 / 1995$
\end{tabular}

Adapted from Kong et al. (2018). 
Related to infrastructure, the most notable investment in facilities was the construction of the Maranhão Grain Terminal (TEGRAM) at the port of São Luís in 2016, which boosted exports of agricultural commodities. Additionally, strong inputs in Information Technology (IT) speeded up communication and business understanding between all economic agents of the agriindustrial system and helped to reduce transaction costs. Respective to environment, the main factor and probably the leading cause of land use changes, seems to be the vast natural area available for agriculture and pasture in East Maranhão.

The primary factor of the third category, economy, is the entrance of global agribusiness players who invested huge amounts in Brazil, especially in the 1990s. In Maranhão, the amounts were directed primary to soybean farmers in order to offer competitive private credits and to keep agents in business, especially during crises.

The fourth category, demography, has been affected primarily by the large number of smallholders's properties, mainly triggered by federal agricultural programs which financed operations of small producers and as well guaranteed public purchase of their output between 2002 and 2010. Very often, such measures permitted reasonable earnings and kept small producers in the rural areas. Data collection and proceedings are resumed in table 2.

Table 2. Data collection and proceeding

\begin{tabular}{|c|c|c|c|}
\hline Analyse & Input & Analytical process & Output \\
\hline 1. Patterns of Land Use & $\begin{array}{l}\text { MapBioma scenes from Landsat } \\
\text { scanner }(1985,1995,2005,2010, \\
2015 \text { and } 2018)\end{array}$ & Geostatistic & $\begin{array}{l}\text { Geographic } \\
\text { illustration }\end{array}$ \\
\hline 2. Farming production & $\begin{array}{l}\text { Official statistics: agricultural } \\
\text { production of municipalities } \\
\text { (1995, 2005, 2010, 2015, and } \\
\text { 2018), livestock production of } \\
\text { municipalities (1995, 2005, 2010, } \\
\text { 2015, and 2018), and farming } \\
\text { census (2017) }\end{array}$ & Quantitative & $\begin{array}{c}\text { Graphic } \\
\text { representation }\end{array}$ \\
\hline
\end{tabular}

3. Understanding the changes

\section{Results and Discussion}


3.1 Land use and farming production analysis

Total forest cover in the East Maranhão decreased during each year of the investigation as shown in figure 3, even though such reduction was not that severe between 1985 and 2018 . There is still considerable land extension fully preserved, but pasture has advanced significantly and become the main responsible for deforestation in the region. Meanwhile, since 2005, agriculture as well has expanded in a large scale. Together, both activities have contributed for most of the transformations occurred, primarily on the southern and northeastern borders.

Apparently, sprawl of current production and introduction of new crops have led to more intense land use all over East Maranhão in the current century. However, as it cannot be assured if the magenta points in figure 3, which characterize agriculture, match with the advance of soybeans crops in this area of study, more empirical evidence is required to determine if soybean production has been responsible for such transformations or not. 
Figure 3. Land use and natural cover in the Caxias Region (1985/2018).

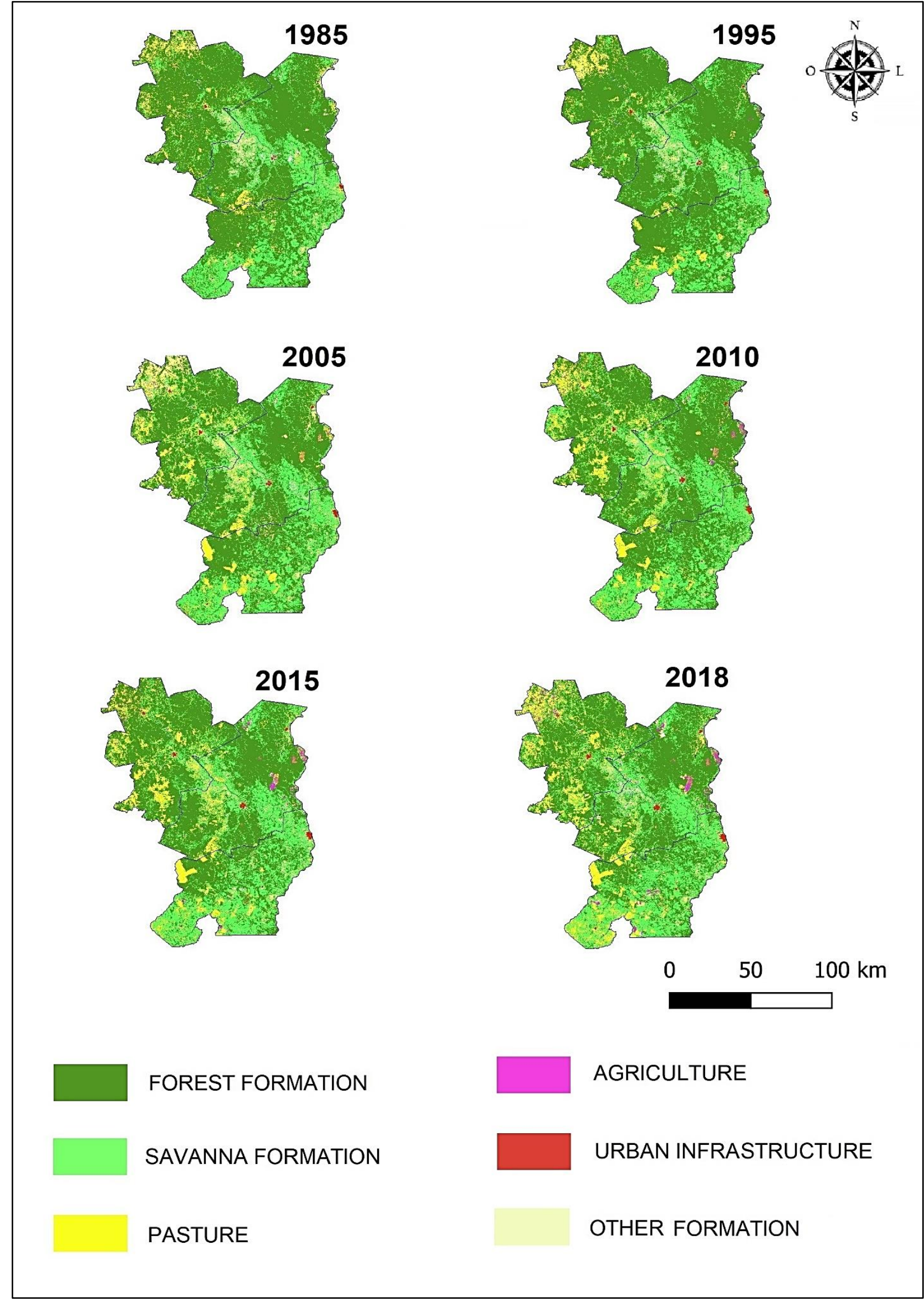

Adapted from Projeto MapBiomas (2019). 
Figure 4 reveals that agriculture increased only 1\% (1985/2018), whereas pasture advanced 5\% in 1985 and $11 \%$ in 2018, respectively. Simultaneously, forest formation decreased 13\% between 1985 and 2018, but its most intense reduction occurred between 1995 and 2005 and later on between 2015 and 2018.

Another concerning figure is the increase of savanna formation by $7 \%$ in the same period, known as "savannization," a process in which dense woodlands are being replaced by poorer biodiversity biomes.

Figure 4. Variation (\%) of land use and land cover between 1985 and 2018 in Caxias Region.

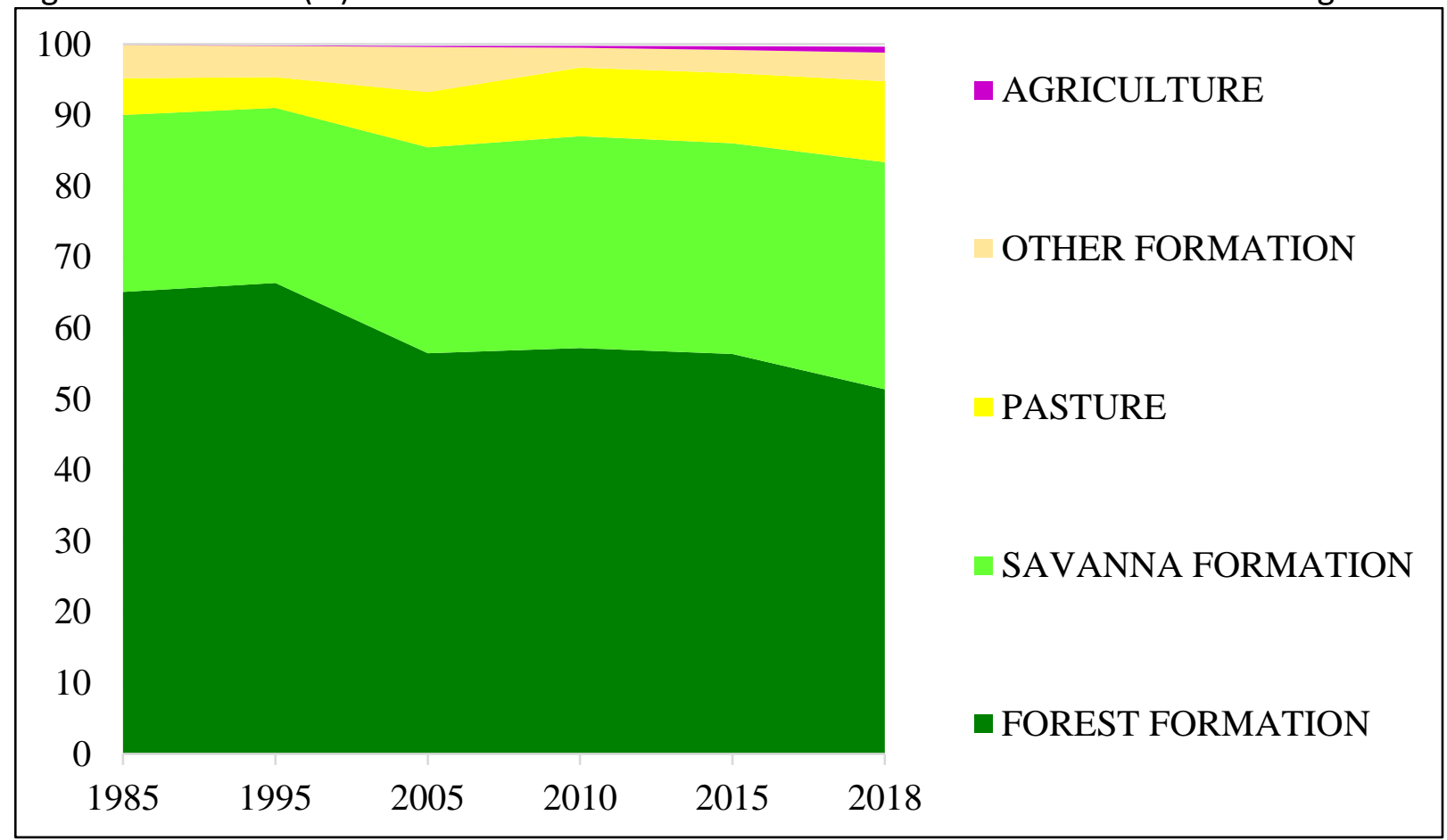

Adapted from Projeto MapBiomas (2019).

According to figures 3 and 4, pasture is the primary land use in East Maranhão, usually employed to cattle breeding. In 1995, the cattle inventory was at 264,369 head and in 2005 already at 328,175 , an increase of more than $24 \%$, the highest variation during the analyzed period (BRASIL, 2019e). In 2018 the number had risen to 375,893, which meant one head of cattle per inhabitant in the area of study. 
Agriculture became relevant in land use in East Maranhão in $1995^{6}$ (figure 5), but soy plantation surged only in 2005, when the municipality of Afonso Cunha, a sub region of Caxias registered its first crop.

Previously, primary regional agricultural production was characterized by rice, and corn, representing 38 and $25 \%$ of the total production in 2005. In the following years, rice production decreased lightly and dropped to $28 \%$ whereas corn maintained its performance and soybeans increased its participation significantly from 2005 to 2018, with a share of almost 18\% (figure 5).

Figure 5. Variation (\%) of cultivated area between 1995 and 2018 in Caxias Region.

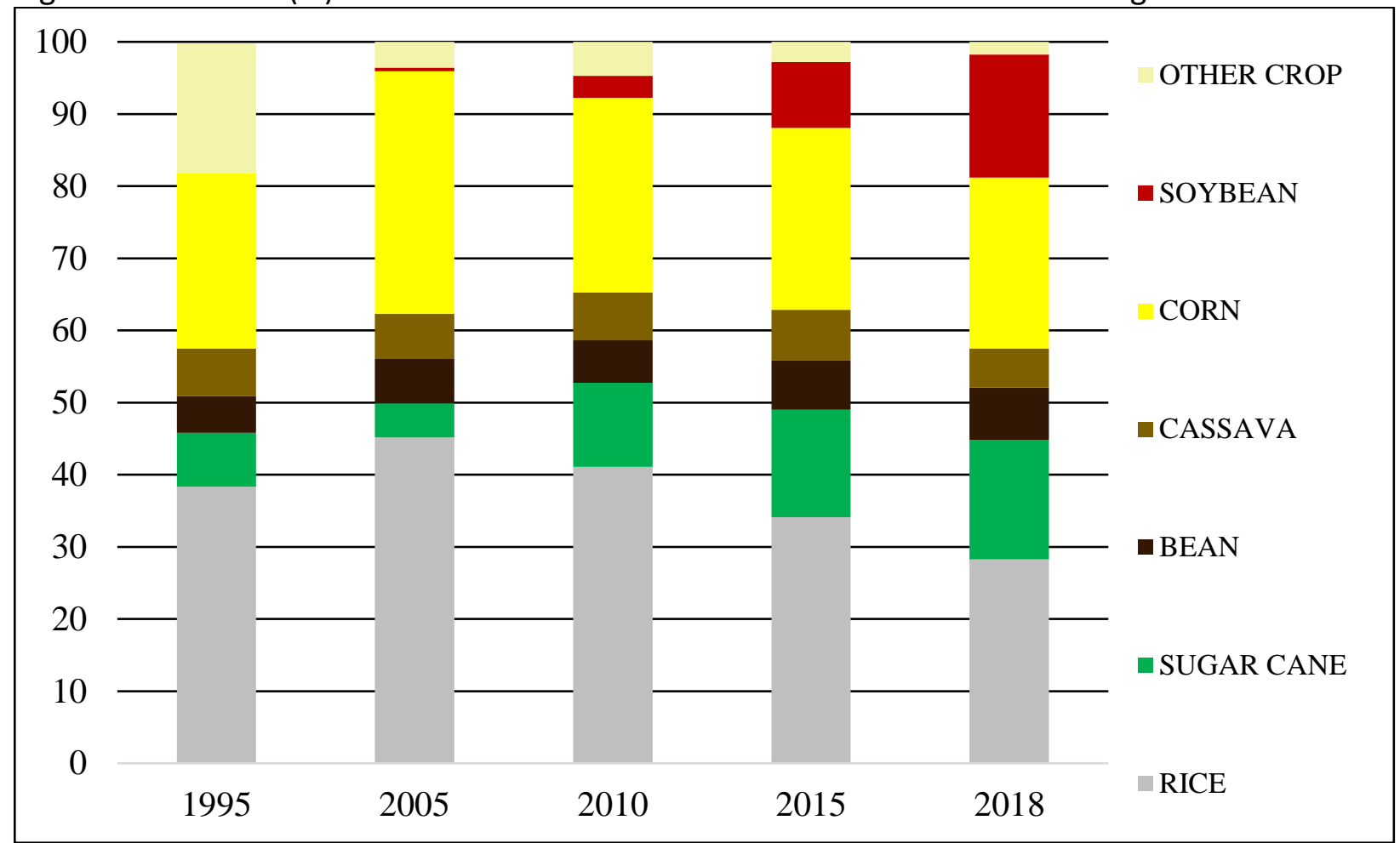

Adapted from Brasil (2019a).

Cassava, beans and sugar cane are other important agricultural products in East Maranhão, cassava, and bean, generally produced by small farmers ${ }^{7}$. Corn is as well essential for these small producers and large landowners. On these latter proprieties, corn productivity, generally based on high-tech equipment and proceedings, exceeds those of the smallholder's yields (SANO et al, 2019; OLIVEIRA; RODRIGUES, 2019).

\footnotetext{
${ }^{6}$ Agricultural Production of Municipalities data by IBGE in 1985 unavailable.

${ }^{7} 88$ percent of rural smallholders used to produce cassava; bean production counts for 83 percent of total regional output (BRASIL, 2019d).
} 
Based on these considerations, we can distinguish two phases which characterize more intense land use changes in the East Maranhão: During the first phase, between 1995 and 2005, pastures for cattle breeding displaced a significant amount of the woodlands, and during the second phase, more recently, between 2015 and 2018, regional agricultural transformations occurred due to the expansion of soy production.

\subsection{Understanding the changes}

The questionnaires and their transcriptions provided by Dorner (2017), were used to circumstantiate previous observations with reference to the four categories and main factors mentioned in table 1.

Only $4 \%$ of the farmers who responded to the interviews produced soybeans in any municipality in East Maranhão during 2015/2016 crop. Brasil (2019d) confirms this low number demonstrating that just one owner planted more than 1,000 hectares of soybeans during $2016 / 2017$ crop. None of the interviewed agents was living in the area of study, even though they were residents of Maranhão state and close to the Caxias Region.

With reference to the category infrastructure, a soybean producer from East Maranhão pointed out that the initiation of the Grain Terminal (TEGRAM) in 2016 at the port of São Luís, most important main public facility recently built, later on tendered and leased to private companies, has opened huge trade opportunities for grain farmers and promoted considerable growth of soy and corn production in the region. Particularly the trade of corn and soybeans to China has reached significant increase. However, insufficient road maintenance has been mentioned as major threat to grain logistics from yields to port.

According to producers, another important factor of infrastructure has been the advance of Information Technology (IT) enabling them to install wireless local area network (WLAN) on their properties, even on remote areas, and obtain benefits from fast track internet. At this stage, they are fully connected to international database and enabled to acquire any information on time, as well as to be permanently linked to suppliers and traders, reducing their transaction cost significantly. Moreover, the formation of producers in WhatsApp groups, has permitted better organization among each other and faster and more efficient exchange of mutual experiences. IT has become a crucial element to promote soybean production in the East Maranhão. 
The second category, environment, mentioned in figure 4 revealed as a main factor the vast availability of natural lands, still covering half of the area of study in 2018. However, according to the interviewed agents, the transformation of forests into agriculture lands has not been simple. Licenses for deforestation, issued by SEMA, the environmental agency of Maranhão state, are subject to very bureaucratic procedures resulting in extreme delays in approval or nonapproval of requirements. Consequently, the lack of legal security exacerbates planning and cash-flow of soybean producers. This scenario differs from the 1970s and 1980s, a period of noneffective government control to reduce deforestation.

Until 2000, online monitoring of deforestation through accurate satellite images was unavailable and local inspection very rare, allowing rural producers to use the original cover nearly unrestrictedly. Nowadays, however, agricultural producers face heavy fines in case of deforestation without the environmental agency's authorization. Such document needs to be renewed every four years. Furthermore, Brazilian environmental laws require to conserve at least $20 \%$ of total property with original Cerrado biome. Nevertheless, a considerable loss of forest formation between 2015 and 2018 can be stated as indicated in figures 3 and 4 .

The third category, economy, characterized by the entrance of major global agribusiness players in the 1990's, according to the interviewed producers, has pushed them to become highly professional, with large investments in technology and workforce to keep competitive and to sustain their position in a tight contractual system as part of a global supply chain.

Such high investments require quick and easy access to loans at low interest rates, mainly granted in a large scale by main global agribusiness players acting in Maranhão. Very often, this has caused financial dependency on international companies, as payback uses to occur by long term soybean supplying contracts, or even, in isolated cases, in case of default, to the loss of some properties.

Regional stakeholders recognize the difficulty of operating in the global commodity markets and expect that this business will become even more challenging in the next decades. Thus, farmers who own land in the Caxias Region seem not to be very interested in cultivating grain on a large scale. Landowners are usually native and more interested in keeping traditional activities such as extensive cattle breeding, whereas the classic soybean producers are generally native from the South of Brazil. As a result, only one single soybean producer succeeded to settle in the examined region. However, in the long term, agriculture in Caxias is also subject to high tech husbandry and should replace traditional activities. 
With reference to the fourth category, demography and its main factor, the area hosts 115 villages and rural settlements and a considerable number of smallholders, representing a strong restriction to the expansion of soybean production, as such high-tech activity demands vast and plain properties to achieve economies of scale. Thus, it seems to be nearly unlikely for investors to become large estate due to extreme elevated transaction cost caused by thousands of spread smallholders.

Consequently, native landowners probably prefer to continue investing in traditional agricultural activities or cattle breeding, rather than to deforest and plant soybeans.

Another limitation to agricultural expansion is the existence of Environmental Protection Areas (APAs), where intensive land use is prohibited. East Maranhão hosts the APA Morro Garapense, with an extension of 375,000 hectars. Its main function is to keep native forests and protect traditional quilombolas and indigenous communities.

According to the results, we identified probable categories and factors to explain the advance of soybean production between 2015 and 2018. The building of facilities such as TEGRAM and the modernization of IT improved infrastructure and made the relationship between grain producers and other trade partners more efficient. Such interactions are absolutely necessary to incorporate East Maranhão into the global commodity market. However, the one hand, the entry of main global agribusiness players contributed to more professionalism in the region, but, on the other, the extreme demand for high-tech and management skills seemed to have discouraged many local rural producers.

Actually, the difficulties to obtain permission for deforestation and the complexity to negotiate with traditional smallholders may considered to be the major obstacles for more soybean production in the area. Previously, between 1995 and 2005, slack environmental regulation, permitted vast deforestation and transformation into wide areas of pasture with cattle breeding, very often without any concern about economic viability.

\section{Conclusions}

Soybean production has not become the main activity in East Maranhão the same way it happened to cotton between 1775 and 1970. Agriculture in East Maranhão is responsible for less than $1 \%$ of total area. Forest and savannah have remained the most important soil use, totaling nearly $88 \%$, nevertheless, whereas the first has but reduced its participation between 1985 and 
2018 from $65 \%$ to $52 \%$, the latter has increased from $25 \%$ to $36 \%$, revealing a tendency of deforestation and savannazation. Pasture continues the main economic activity increased its participation of soil use from $5 \%$ to $10 \%$.

The expansion of soybeans has been hampered by an elevated number of small properties and environmental restrictions which have not permitted the takeover of vast land for high-tech production and permission for deforestation. The main challenge may consider a consensus among the protecting of areas with original cover and traditional communities, and the creation of competitive regional agricultural production of commodities as part of global supply chains. Hence, a probable framework with multitasked farming activities, on the contrary to monoculture, which seemed to become dominant in Brazilian rural regions, should be prioritized.

Mapbioma has proved to be an excellent tool to investigate land use in the Cerrado. The research should be expanded to other areas of MATOPIBA in order to reveal deforestation and savannization. Sustainable agriculture means production of commodities, important for Brazilian trade balance, in accordance with the preservation of existing natural vegetation and reforestation of degenerated areas $^{8}$.

\section{References}

ABRAMSON, M; HAGBERG, J-M. What about community sustainably? - dilemmas of ageing in shrinking semi-rural areas in Sweden. Scottish Geographical Journal, n.134, v.3-4, p.103-121, 2018. DOI: https://doi.org/10.1080/14702541.2018.1527941

ALMEIDA, J. G.; MATTOS JÚNIOR, J. S. A dinâmica da produção de soja no município de Brejo (MA) e seus reflexos na produção agrícola camponesa. Campo-Território: revista de geografia agrária, Uberlândia, v. 11, n. 24, p. 374-399, Aug. 2016.

ARAÚJO, M. L. S.; SANO, E. E.; BOLFE, E. L.; SANTOS, J. R. N.; SANTOS, J. S.; SILVA, F. B. Spatiotemporal dynamics of soybean crop in the Matopiba region, Brazil (1990-2015). Land use policy, v.80, p.57-67, 2019. DOI: https://doi.org/10.1016/j.landusepol.2018.09.040

BECKMANN, E.; SANTANA, A. C. Modernização da agricultura na nova fronteira agrícola do Brasil: MATOPIBA e Sudeste do Pará. Revista em Agronegócio e Meio Ambiente, Maringá (PR), v. 12, n. 1, p. 81-102, Jan.Mar. 2019. DOI: https://doi.org/10.17765/2176-9168.2019v12n1p81102

BRASIL. INSTITUTO BRASILEIRO DE GEOGRAFIA E ESTATístICA. Produção Agrícola Municipal. Available at: < https://sidra.ibge.gov.br/pesquisa/pam/tabelas >. Accessed on: Aug. 5 2019a.

\footnotetext{
8 Unfortunately, we are seeing the prevalence of a simplify rural development speech in Brazil (MIRANDA et al.,
} 2020). 
. MINISTÉRIO DA AGRICULTURA, PECUÁRIA E ABASTECIMENTO. Balança Comercial Agronegócio - Junho 2018. Available at: <http://www.agricultura.gov.br/noticias/saldo-dabalanca-do-agro-em-junho-e-de-us-8-17-bilhoes/Junho2018.docx>. Accessed on: Aug. 7 2019b.

. INSTITUTO BRASILEIRO DE GEOGRAFIA E ESTATÍ́STICA. Estimativas da População. Available at: < https://sidra.ibge.gov.br/pesquisa/estimativas>. Accessed on: Aug. 29 2019c.

. INSTITUTO BRASILEIRO DE GEOGRAFIA E ESTATÍ́sTICA. Censo Agropecuária 2017. Available at: < https://sidra.ibge.gov.br/pesquisa/pam>. Accessed on: Nov. 21 2019d.

. INSTITUTO BRASILEIRO DE GEOGRAFIA E ESTATÍ́STICA. Produção Pecuária Municipal. Available at: < https://sidra.ibge.gov.br/pesquisa/pam/tabelas>. Accessed on: Dec. 2 2019e.

DUTRA, J. A. A.; AREND, S. C. Tecnologia de informação e desenvolvimento agrícola regional: estudo de caso em Balsas/MA. Informe Gepec, Toledo, PR, v.19, n.2, p. 23-40, Jul.Dec. 2015.

DORNER, S. Análise do sistema agroindustrial da soja e seus efeitos sobre o desenvolvimento econômico e social do Maranhão. 2017. 325p. Tese (Doutorado) - Universidade Estadual do Oeste do Paraná, Toledo.

; OLIVEIRA, T.; SCHNEIDER, M. Maranhão: comparação da competitividade dos ciclos da cotonicultura (1755-1970) e da sojicultura (desde 1980). Revista de Geografia e Ordenamento do Território (GOT), n. 16, p. 125-152 Mar. 2019. DOI:

https://doi.org/10.17127/got/2019.16.006

ELIAS, D. Reestruturação produtiva da agropecuária e novas regionalizações no Brasil. In: ALVES, V. E. L (org). Modernização e regionalização nos Cerrados do Centro Norte do Brasil: Oeste da Bahia, Sul do Maranhão e do Piauí e Leste de Tocantins. Rio de Janeiro: Consequência Editora, p. 25-44, 2015.

. Construindo a noção de Região Produtiva do Agronegócio. OLIVEIRA, H.C.; CALIXTO, M. J. M. S.; SOARES, B. R. (orgs.). In: Cidades médias e região. São Paulo: Cultura Acadêmica, 2017. . Interações entre o rural e o urbano a partir do agronegócio globalizado e desenvolvimento regional. SILVEIRA, R. L. L. S.; FELIPPI, A. C. T. (orgs.). In: Territórios, redes e desenvolvimento regional: perspectivas e desafio. Florianópolis: Editora Insular, 2018.

GOMES E.; ABRANTES, P.; BANOS, A.; ROCHA, J.; BUXTON, M. Farming under urban pressure: farmers land use and land cover change intentions. Applied Geography, v.102, p.58-70, 2019. DOI: https://doi.org/10.1016/j.apgeog.2018.12.009

KONG R.; DIEPART, J. C.; CASTELLA, J. C.; LESTRELIN G.; TIVET, F.; BELMAIN E.; BÉGUÉ, A. Understanding the drivers of desforestation and agricultural transformations in the Northwestern uplands of Cambodia. Applied Geography, v. 102, p.84-98, 2018. DOI: https://doi.org/10.1016/j.apgeog.2018.12.006

MIRANDA, E.; CARVALHO, C. A.; MARTINHO, P. R. R.; OSHIRO, O. T. Contribuições do geoprocessamento à compreensão do mundo rural e do desmatamento no bioma Amazônia. Colóquio - Revista do Desenvolvimento Regional, Taquara, RS, v.17, n.1, jan/mar, 2020. DOI: https://doi.org/10.26767/coloquio.v17i1.1576

PROJETO MAPBIOMAS. Coleção 4 da série anual de mapas de cobertura e uso de solo do Brasil. Available at: < http://mapbiomas.org/pages/scripts. Acessed on: Nov. 92019. 
OLIVEIRA, T. J. A.; RODRIGUES, W. Uma análise espacial da estrutura produtiva no interior do Brasil: os clusters do agronegócio. Rev. Econ. NE, Fortaleza, v. 50, n. 1, p. 153-170, Jan.Mar. 2019.

PERPETUA, G. M.; COSTA, S. B.; THOMAZ JÚNIOR, A. The advance of commodities and the territorial looting in Maranhão. Braz. J. of Develop., Curitiba, v. 5, n. 1, p. 1611-1630, Jan. 2019. SANO, E. E.; ROSA, R.; SCARAMUZZA, C. A. M.; et al. Land use dynamics in the Brazilian Cerrado in the period from 2002 to 2013. Pesquisa Agropecuária Brasileira, Brasília, v.54, 2019. DOI: https://doi.org/10.1590/S1678-3921.pab2019.v54.00138 